\title{
AKTIVITAS ANTIMALARIA TANAMAN TALI KUNING (Anamirta cocculus) TERHADAP Plasmodium sp.
}

\author{
Marhamah1, Ismalia Husna2
}

1Jurusan Analis Kesehatan Politeknik Kesehatan Tanjungkarang

2Departemen Parasitologi Fakultas Kedokteran, Universitas Malahayati

\begin{abstract}
Antimalarial Activity of Anamirta cocculus against Plasmodium sp. Malaria is one of the causes of death in children and adults, especially pregnant women in the tropics. Increased parasitic resistance to existing malaria drugs is one of the causes of the high morbidity and mortality rates. That is why the development of malaria drugs derived from plants is currently intense, one of them was Anamirta cocculus. The antimalarial mechanism of berberine compounds in Anamirta cocculus is causing by inhibiting the activity of Plasmodium $s p$ telomerase in the intraeritrocytic Plasmodium development cycle, especially in the tropozoid and schizon stages. Compounds in the form of quaternary ammonium have been known to inhibit the growth of Plasmodium by blocking intracellular transport of choline. Choline compounds are needed for phospholipid biosynthesis in the formation of parasitic membranes to cover parasitophorous vacuole, cytosol and various subcellular compartments. This block of choline transport has been used as a malaria treatment strategy.
\end{abstract}

Keywords: Malaria, Plasmodium sp, Anamirta cocculus

\begin{abstract}
Abstrak: Aktivitas Antimalaria Tanaman Tali Kuning (Anamirta cocculus) terhadap Plasmodium sp. Penyakit malaria merupakan salah satu penyebab kematian pada anak-anak dan dewasa khususnya ibu hamil di daerah tropis. Meningkatnya resistensi parasit terhadap obat malaria yang ada merupakan salah satu penyebab tingginya angka morbiditas dan mortalitas. Karena itulah pengembangan obat malaria yang berasal dari tanaman saat ini gencar, salah satunya dengan pemanfaatan tanaman tali kuning (Anamirta cocculus). Mekanisme antimalaria senyawa berberine pada tanaman tali kuning yaitu dengan menghambat aktivitas telomerase Plasmodium $s p$ pada siklus perkembangan plasmodium intraeritrositik terutama pada tahap tropozoid dan skizon. Senyawa dalam bentuk ammonium kuarterner telah diketahui dapat menghambat pertumbuhan Plasmodium dengan cara memblok transport intraseluler kolin. Senyawa kolin diperlukan untuk biosintesis phospholipid dalam pembentukan membran parasit untuk menutup parasitophorous vacuole, sitosol dan berbagai subseluler kompartemen. Pengeblokan transport kolin ini telah digunakan sebagai salah satu strategi pengobatan malaria.
\end{abstract}

Kata Kunci: Malaria, Plasmodium sp, Anamirta cocculus

\section{PENDAHULUAN}

Penyakit malaria merupakan salah satu penyebab kematian pada anak-anak dan dewasa khususnya ibu hamil di daerah tropis (WHO, 2010). Di Indonesia, malaria tergolong penyakit masih menjadi masalah utama dalam bidang kesehatan. Tahun 2006-2009, Kejadian Luar Biasa (KLB) selalu terjadi di pulau Kalimantan walaupun kabupaten/kota yang terjangkit berbeda-beda tiap tahun. Pada tahun 2009, KLB dilaporkan terjadi di pulau Jawa (Jawa Tengah, Jawa Timur dan Banten), Kalimantan (Kalimantan
Selatan), Sulawesi (Sulawesi Barat), NAD dan Sumatera (Sumatera Barat dan Lampung) dengan total jumlah penderita adalah 1.869 orang dan meninggal sebanyak 11 orang. KLB terbanyak di pulau Jawa yaitu sebanyak 6 kabupaten/kota (Depkes RI, 2011). Akhir-akhir ini upaya pemberantasan penyakit malaria mengalami hambatan dengan adanya resistensi parasit terhadap beberapa obat antimalaria. Meningkatnya resistensi parasit terhadap obat malaria yang ada merupakan salah satu penyebab tingginya angka morbiditas 
dan mortalitas. Penyebab resistensi utama adalah karena adanya mutasi pada gen-gen dari Plasmodium. Pada tahun 1989 muncul laporan resistensi $P$. vivax terhadap klorokuin pada 2 orang prajurit Australia yang kembali dari Papua Nugini. Prajurit tersebut terinfeksi $P$. vivax walaupun telah mendapat profilaksis dengan klorokuin dosis 300 $\mathrm{mg}$ per minggu. Pengobatan dengan klorokuin dosis $600 \mathrm{mg}$ yang diberikan kepada prajurit tersebut di rumah sakit juga tidak menghilangkan parasitemia. Sejak itu banyak laporan resistensi $P$. vivax dari Papua Nugini, yang kemudian menyusul laporan dari beberapa negara yang umumnya berasal dari Asia Tenggara (Rieckman et al, 1989). Di Indonesia, adanya resistensi $P$. vivax terhadap klorokuin pertama kali di laporkan pada tahun 1991 di Irian Jaya, kemudian menyusul laporan dari Sumatera, Kalimantan, dan beberapa daerah lain di Indonesia (Nurhayati, 2008).

Karena itulah pengembangan obat malaria yang berasal dari tanaman saat ini gencar dilakukan. Selain itu adanya penemuan dan keberhasilan tanaman Artemisia annua (Qinghaosu) dari family Asteraceae di Cina pada tahun 1970 telah diterima di seluruh dunia untuk pengobatan resistensi malaria dan membuat perhatian dunia terpusat pada pengembangan obat antimalaria dari tanaman (Taylor \& Berridge, 2006).

Tanaman tali kuning (Anamirta cocculus) terutama bagian batangnya telah diteliti aktivitas antimalarianya terhadap Plasmodium berghei, dimana Plasmodium ini memiliki morfologi dan siklus hidup yang hampir sama seperti parasit malaria pada manusia yaitu perpaduan antara sifat dari Plasmodium falciparum dan Plasmodium vivax (Richardson \& Sauchyn, 2007). Berdasarkan penelitian-penelitian yang telah dilakukan, maka dinyatakan bahwa tanaman tali kuning (Anamirta cocculus) memiliki aktivitas antimalaria, tetapi belum banyak yang menggambarkan bagaimana mekanisme kerja dari aktifitas tanaman tali kuning ini dalam mengeliminasi malaria.

\section{PEMBAHASAN}

\section{Malaria}

Malaria merupakan salah satu penyakit yang memiliki efek yang sangat serius di seluruh dunia. Penyebarannya semakin meningkat seiring dengan munculnya resistensi senyawa kimia berupa obat terhadap parasit maupun vektornya (Daugherty, 1997).

Penyakit malaria sendiri terdiri dari 5 spesies yakni malaria kuartana yang disebabkan oleh Plasmodium malariae, malaria tropika yang disebabkan oleh Plasmodium falciparum, dan malaria tersiana yang disebabkan oleh Plasmodium vivax dan $P$. ovale serta malaria yang berasal dari hewan dan dapat menginfeksi ke manusia yaitu Plasmodium knowlesi. Dalam proses penyebaran penyakit malaria, Plasmodium memiliki dua hospes diantaranya manusia dan nyamuk Anopheles betina. Manusia merupakan hospes perantara, yaitu tempat nyamuk melakukan skizogoni atau fase aseksual, sedangkan nyamuk Anopheles betina sebagai hospes definitif, yaitu tempat terjadinya siklus seksual dan reproduksi yang dilengkapi dengan sporogoni (Zucker, 1996).

Siklus hidup Plasmodium dimulai dari proses inokulasi sporozoit malaria ke dalam hospes manusia yang terjadi karena gigitan nyamuk terinfeksi yang akan mengantarkan sporozoit dari kelenjar ludah nyamuk ke aliran darah manusia yang kemudian menuju hepatosit atau hati (Sullivan \& Krishna, 2005). Kemudian dalam waktu 30-60 menit seluruh parasit akan masuk ke dalam hati dan tidak ada yang tersisa di sirkulasi darah. Setelah berada di hati, Plasmodium akan menggandakan diri secara aseksual. Proses ini akan terus berlangsung 9-16 hari sebelum memasuki sel darah merah (Marcus, 2009).

Sporozoit akan segera hilang dari sirkulasi darah dan kemudian menggandakan diri di sel parenkim hati hingga berkembang menjadi skizon jaringan, bagian ini dikenal sebagai fase pre-eritrosit atau eksoeritrosit dan berlangsung selama 5-15 hari, hal ini tergantung pada jenis Plasmodium. Plasmodium vivax dan Plasmodium ovale memiliki fase dorman yang dikenal 
dengan hipnozoit yang berada di dalam hati selama beberapa minggu hingga beberapa tahun sebelum perkembangan skizogoni pre-eritrosit (Perlmann \& Troye, 2002).

Setelah mengalami perkembangan, skizon jaringan akan pecah dan melepaskan 10.000 merozoit di sirkulasi darah. Lalu merozoit akan berkembang menjadi parasit intraeritrositik (fase cincin) yang matang menjadi tropozoit dan skizon dalam eritrosit pada 48-72 jam setelahnya (Sullivan \& Krishna, 2005). Kurang dari $1 \%$ merozoit berdiferensiasi dalam eritrosit menjadi bentuk seksual yaitu makrogametosit (betina) dan mikrogametosit (jantan). Proses gametogenesis dalam nyamuk Anopheles akan dilanjutkan dengan proses pembuahan makrogamet untuk membuat zigot. Dalam waktu 24 jam, zigot akan berdiferensiasi menjadi ookinet yang kemudian akan menjadi ookista. Ribuan sporozoit baru diproduksi dari ookista dan bermigrasi ke kelenjar ludah menuju ke epitelium kelenjar dan akhirnya masuk ke dalam hospes manusia selama proses konsumsi darah, sebagaimana yang tertera pada Gambar 1 (Sullivan \& Krishna, 2005).

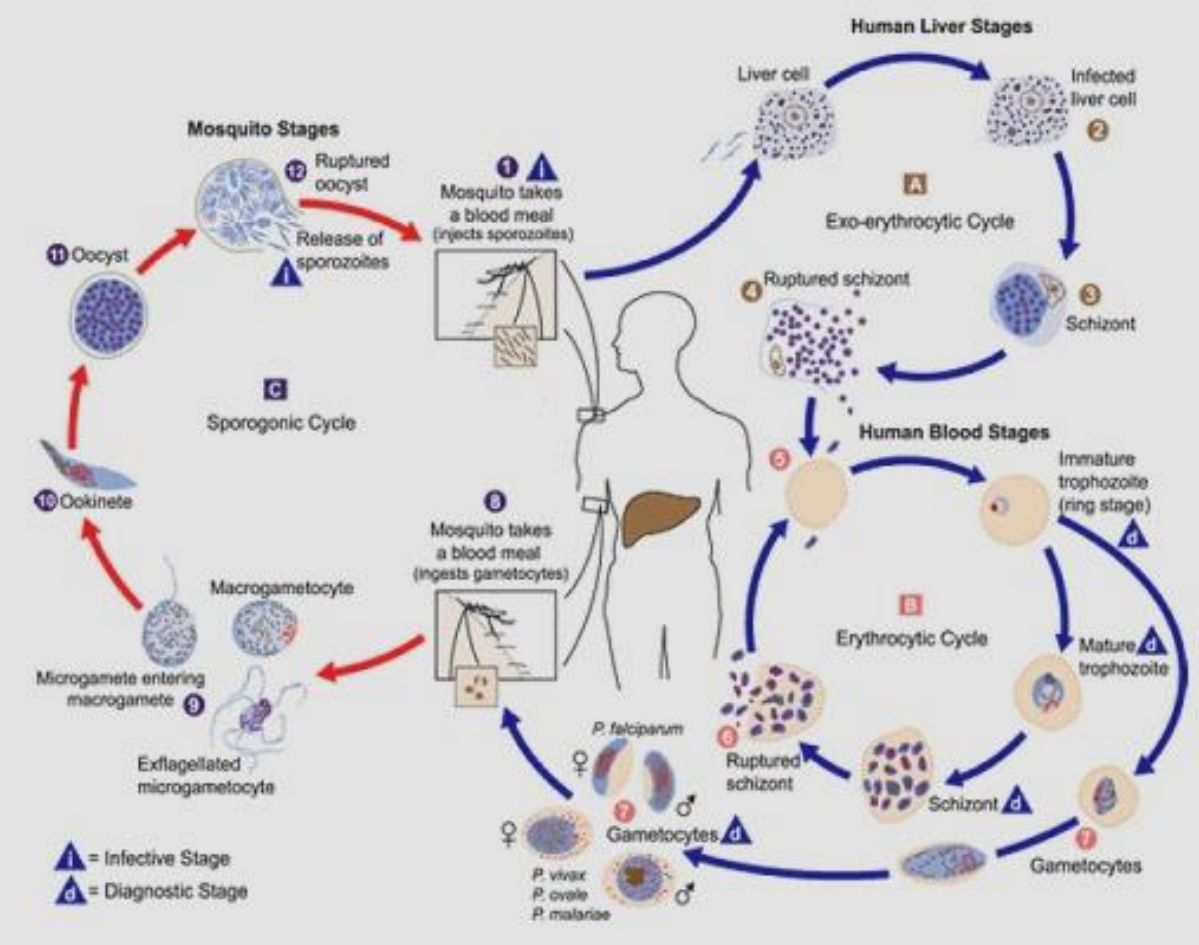

Gambar 1. Siklus hidup Plasmodium

\section{Tali Kuning (Anamirta cocculus)}

\subsection{Klasifikasi}

Klasifikasi dari tanaman tali kuning atau Anamirta cocculus adalah sebagai berikut:

$\begin{array}{ll}\text { Regnum } & \text { : Plantae } \\ \text { Divisi } & : \text { Spermatophyta } \\ \text { Sub divisi } & : \text { Angiospermae } \\ \text { Kelas } & : \text { Dikotil } \\ \text { Bangsa } & \text { : Ranales } \\ \text { Suku } & : \text { Menispermaceae } \\ \text { Marga } & : \text { Anamirta } \\ \text { Jenis } & \text { : Anamirta cocculus } \\ \text { (Heyne, 1950). }\end{array}$

\subsection{Morfologi}

Tanaman tali kuning atau Anamirta cocculus merupakan tanaman yang tumbuh dengan baik di daerah dataran rendah sekitar $800 \mathrm{~m}$ diatas permukaan laut. Tanaman ini banyak tumbuh liar di daerah pantai dan juga semak belukar (Becker, 1963).

Anamirta cocculus merupakan tanaman yang merambat dengan arah putaran ke kiri, panjangnya dapat mencapai 20m. Tanaman 
ini memiliki batang berkayu, warnanya putih kekuningan dan memiliki rasa pahit. Daunnya berbentuk jantung tebal dan kaku dengan tangkai yang panjang, permukaan daunnya mengkilap. Bunga dari Anamirta cocculus ini kecil-kecil dan tumbuh pada batang yang sudah tua, sedangkan pada batang atau tangkai besar terdapat buahnya yang berwarna kuning dan kemudian menjadi hitam setelah tua. Buah dari tanaman ini keras dan berbentuk bulat, serta didalamnya berisi sebuah biji yang tipis (Heyne, 1950). Morfologi tanaman tali kuning (Anamirta cocculus) dapat dilihat pada Gambar 2.
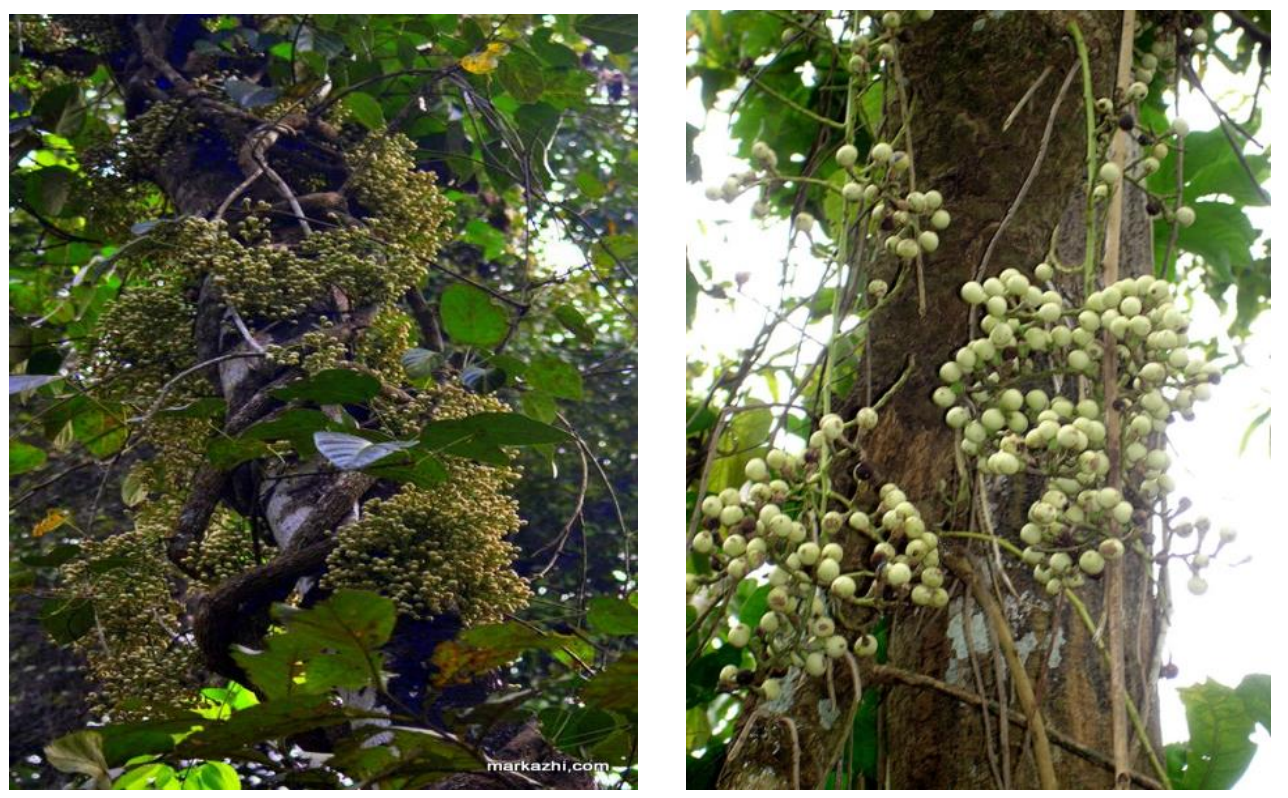

Gambar 2. Tanaman tali kuning (Anamirta cocculus)

Tumbuhan ini telah lama dikenal di Indonesia, seperti terlihat pada berbagai nama daerahnya yaitu tuba biji (Sumatera), oyod peron (Jawa), tuba tuni (Ambon), beri (Ternate), bun peperon (Bali), raoeraoe (Halmahera), hamurut (Maluku), kelebo atau bun peperon (Nusatenggara) (Heyne, 1950).

\subsection{Senyawa Kimia Tali Kuning}

Tanaman tali kuning (Anamirta cocculus) adalah tanaman obat yang secara empiris telah digunakan sebagai obat antimalaria di Papua. Penelitian tentang isolasi dan identifikasi senyawa kimia pada tanaman tali kuning memberikan hasil adanya senyawa alkaloid kuartener pada akar dan batang tanaman tersebut. Alkaloid kuartener tersebut adalah berberine, palmatine, magnoflorine dan columbamine (Ropivia et al, 2010).

Pada penelitian sebelumnya, hasil isolasi berberine yang diperoleh dari akar Thalictrum flavum dan palmatine yang diperoleh dari tanaman Peniantus longifolius dilaporkan mempunyai aktivitas sebagai antimalaria yang poten (Titanji et al, 2008).

Struktur dari senyawa berberine, palmatine, magnoflorine, dan columbamine dapat dilihat pada gambar 3. 
<smiles>COc1ccc2cc3[n+](cc2c1OC)CCc1cc2c(cc1-3)OCO2</smiles>

Berberine<smiles>COc1ccc2c(c1O)-c1c(O)c(OC)cc3c1[C@@H](C2)[N+](C)(C)CC3</smiles>

Magnoflorine<smiles>COc1cc2c(cc1OC)-c1cc3ccc(OC)c(OC)c3cc1N(O)CC2</smiles>

Palmatine<smiles>COc1cc2c(cc1OC)c1ccc(OC)c(OC)c1c1cc(OC)c(OC)cc21</smiles>

Columbamine

Gambar 3. Struktur senyawa alkaloid kuartener

Senyawa alkaloid kuartener (berberine, palmatine, magnoflorine dan columbamine) merupakan struktur senyawa yang mengandung nitrogen kuartener yang telah diketahui dapat menghambat pertumbuhan Plasmodium dengan cara memblok transport intraseluler kolin (Ancelin \& Vial, 1989). Senyawa kolin diperlukan untuk biosintesis phospholipid dalam pembentukan membran parasit untuk menutup parasitophorous vacuole, sitosol dan berbagai subcellular compartement. Pengeblokan transport kolin ini telah digunakan sebagai salah satu strategi pengobatan malaria (Rosenthal, 2003). Senyawa berberine, palmatine, magnoflorine dan columbamine ini juga digolongkan ke dalam golongan kuinolin, dimana golongan tersebut telah diketahui mampu membunuh parasit malaria dengan mekanisme kerja pada food vacuole parasit yaitu dengan mencegah pembentukan "heme polymerase" sehingga hemozoin tidak terbentuk (Rosenthal, 2003).

\section{Aktivitas Antimalaria}

Sebuah penelitian dari Uswatun Chasanah dkk menunjukkan bahwa ekstrak batang Anamirta cocculus mampu menurunkan pertumbuhan Plasmodium falciparum in vitro (Gambar 4). 


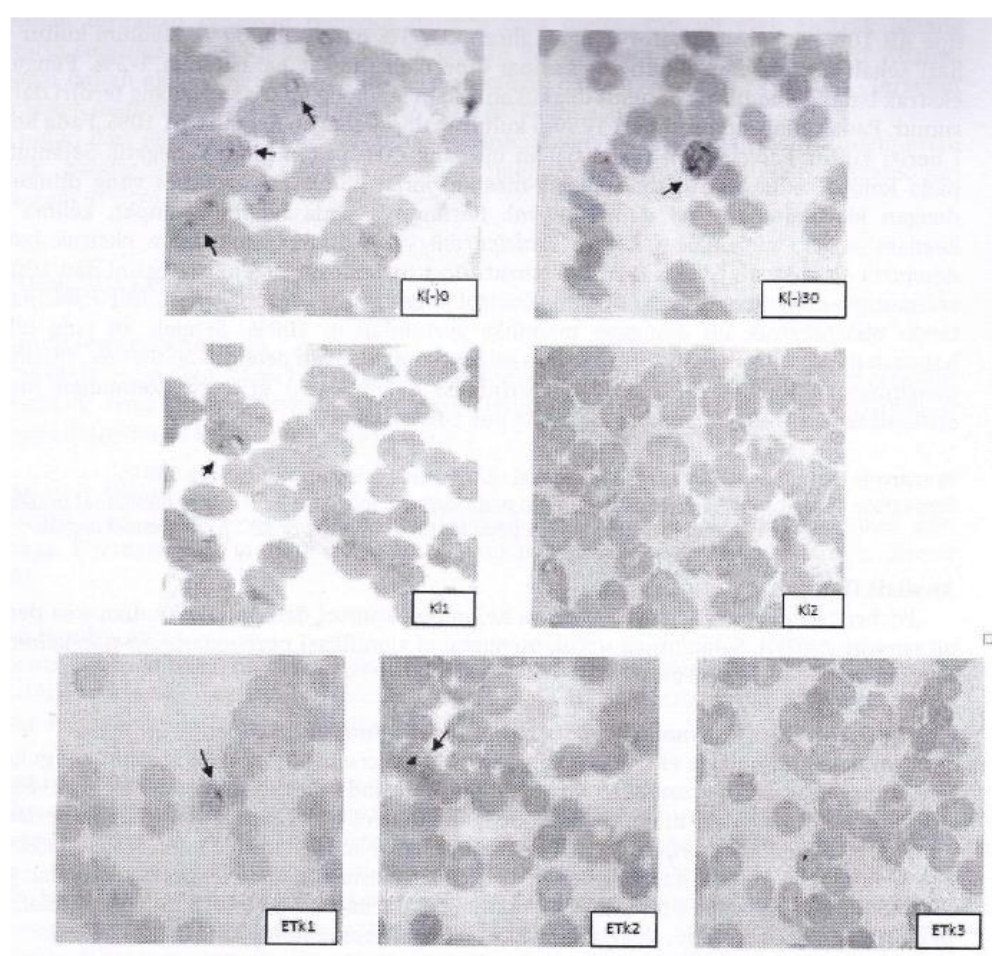

Gambar 4. Penurunan jumlah Plasmodium falciparum pada sel darah merah

Penurunan pertumbuhan Plasmodiun falciparum akibat pemberian ekstrak batang Anamirta cocculus ini membuktikan bahwa batang Anamirta cocculus mengandung senyawa aktif yang mempunyai aktifitas sebagai obat antimalaria. Senyawa aktif tersebut diduga adalah alkaloid kuarterner yaitu berberin, palmatin, columbamin, dan magnoflorin. Dugaan bahwa senyawa alkaloid kuartener tersebut mempunyai aktifitas sebagai antimalaria telah dibuktikan oleh Wright C.W. et.al yang telah meneliti aktivitas antiplasmodial berberin terhadap Plasmodium falciparum $\mathrm{K} 1$ in vitro (Wright et al, 2000). Mekanisme berberine sebagai antiplasmodial telah dilakukan penelitian oleh N.Sriwilaiiareon et al yang menyatakan bahwa berberine yang diekstraksi dari Arcangeiisia flava (L.)Merr., menghambat aktivitas telomerase Plasmodium falciparum pada siklus perkembangan plasmodium intraeritrositik terutama pada tahap tropozoid dan skizon (Sriwilaijareon et al, 2002).

Terdapat beberapa obat antimalaria dengan struktur dasar kuinolin, diantaranya adalah 4-aminokuinolin.
Obat antimalaria yang termasuk golongan 4-aminokuinolin adalah klorokuin dan amodiakuin. Oleh sebab itu aktivitas antimalaria dari ektrak batang tali kuning (berberin, palmatin, magnoflorin dan columbamin) diduga pula melalui penghambatan pembentukan hemozoin. Hemozoin atau pigmen malaria adalah polimer heme yang diproduksi oleh Plasmodium sp selama degradasi hemoglobin dalam food vacoule. Hemozoin ini berada pada semua bentuk plasmodium yang terdapat dalam sel darah merah, yaitu bentuk cincin, tropozoit, skizon maupun gametosit. Dengan ditemukannya heme polymerase, yang merupakan suatu enzim yang mengkatalis polimerisasi dari ferrriprotoporphyrine IX (FP IX) menjadi bentuk $\beta$-hematin, semakin memperkuat dugaan bahwa klorokuin menurunkan produksi hemozoin dengan cara mempengaruhi kerja heme polymerase (Chasanah et al, 2011). Sementara itu mekanisme antimalaria pada golongan kuinolin dapat dilihat pada Gambar 5 dan mekanisme penghambatan pembentukan hemozoin dapat dilihat pada Gambar 6. 

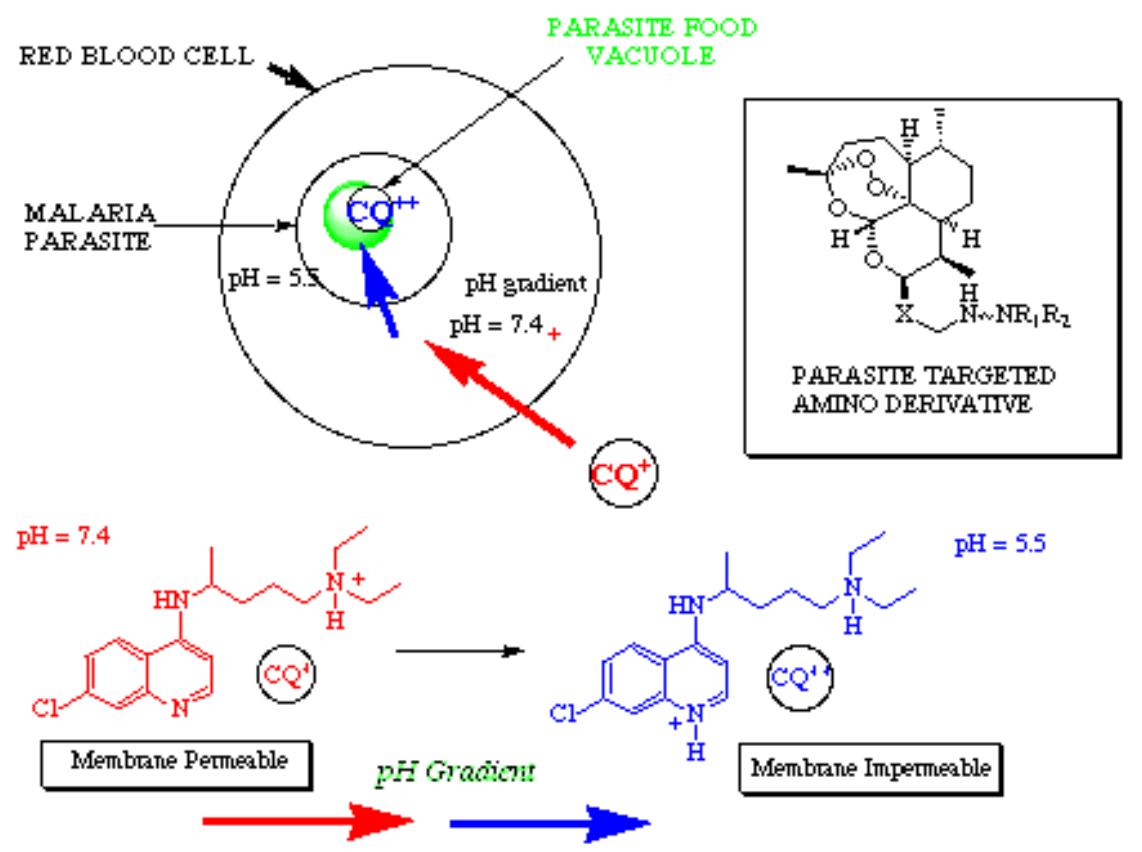

Gambar 5. Mekanisme antimalaria pada golongan kuinolin

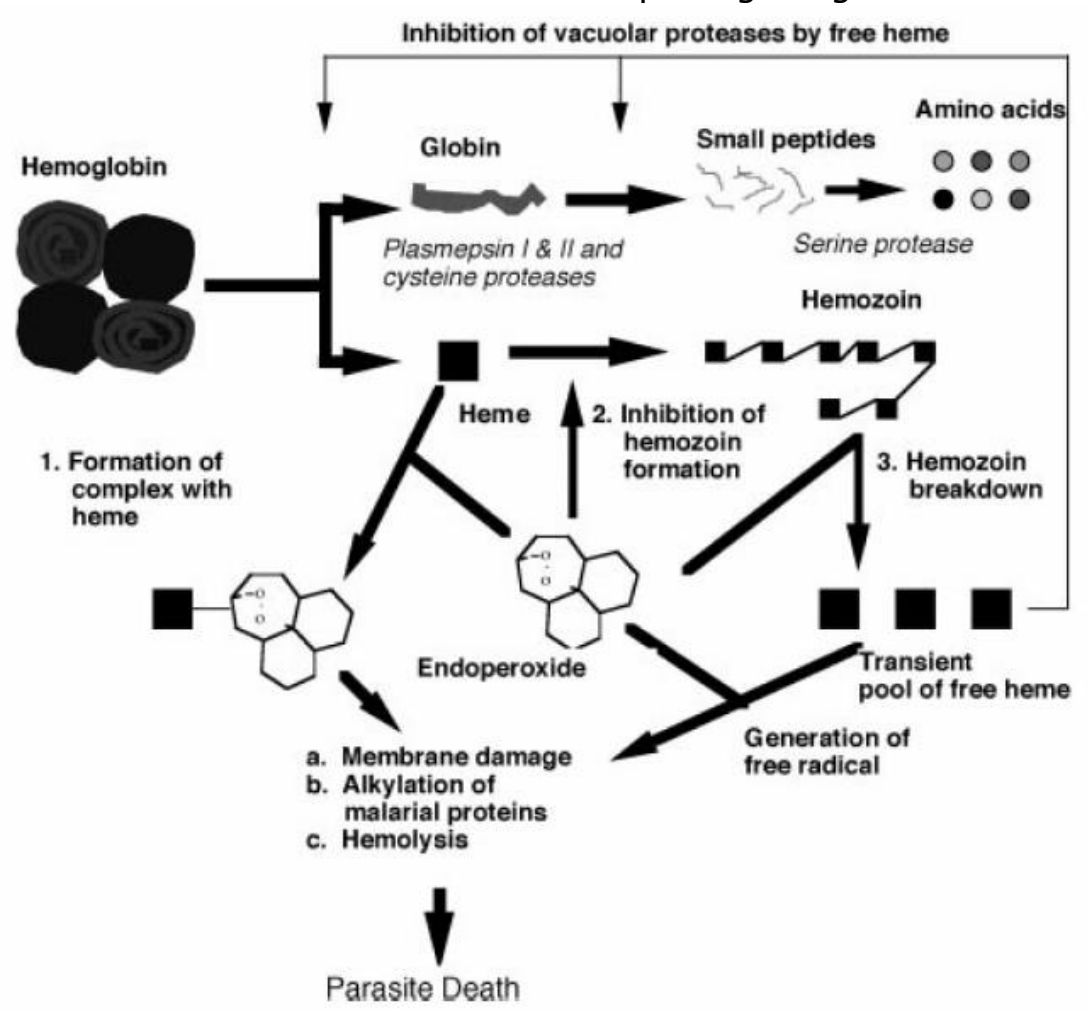

Gambar 6. Mekanisme penghambatan polimerisasi heme menjadi hemozoin

Senyawa berberine, palmatin, magnoflorin dan columbamin juga dapat digolongkan sebagai senyawa amonium kuarterner. Senyawa dalam bentuk ammonium kuarterner telah diketahui dapat menghambat pertumbuhan Plasmodium dengan cara memblok transport intraseluler kolin. Senyawa kolin diperlukan untuk biosintesis phospholipid dalam pembentukan membran parasit untuk menutup parasitophorous vacuole, sitosol dan berbagai subseluler kompartemen. Pengeblokan transport kolin ini telah digunakan sebagai salah satu strategi pengobatan malaria. Atas dasar persamaan struktur dari keduanya yakni merupakan senyawa amonium kuarterner, menjadi dasar dugaan bahwa mekanisme aksi antimalaria 
ekstrak batang talikuning boleh jadi juga dengan cara memblok transportkolin (Chasanah et al, 2011).

Pada penjelasan-penjelasan tersebut dapat diketahui bahwa tanaman tali kuning (Anamirta cocculus) memiliki 3 mekanisme aktivitas antimalaria, yakni menghambat aktivitas telomerase Plasmodium falciparum pada siklus perkembangan plasmodium intraeritrositik terutama pada tahap tropozoid dan skizon, menghambat pembentukan hemozoin, dan menghambat transport kolin, karena itu tanaman tali kuning ini dapat dijadikan sebagai salah satu alternatif obat antimalaria untuk membunuh Plasmodium.

\section{DAFTAR PUSTAKA}

Ancelin M.L., and Vial H.J. (1989). Quaternary Ammonium Coumpounds Efficiently Inhibit Plasmodium falciparum Growth In Vitro by Impairment of Choline Transport, Antimicrobial Agent and Chemotherapy. 29: 814-20.

Becker, G.A., Brink. R.c., (1963), "Flora of Java" Netherlands, 155-6.

Chasanah, U., Dorta Simamora, Sasangka PrasetyawanS., Loeki Enggar Fitri. (2011). Uji Aktivitas Antimalaria Ekstrak Batang Talikuning (Anamirta cocculus (L.) Wight\&Arn.) In Vitro. Kongres Ilmiah Ikatan Apoteker Indonesia ke XIX, Manado 28-30 Oktober 2011.

Daugherty, J.R. (1997). BaculovirusMediated expression of Plasmodium falciparum erythrocyte binding antigen 175 polypeptides and their recognition by human antibodies. American Society for Microbiology, 65, 3631-7.

Depkes RI. (2011). Epidemiologi Malaria. Buletin Jendela Data dan Informasi Kesehatan, Volume 1, Triwulan 1.

Heyne, K. (1950). De Nuttige Plante van Indonesie. Gravenhage, 620-1

Marcus, B. (2009). Deadly Diseases and Epidemics Malaria Second Edition . New York: Chelsea House.
Nurhayati. (2008). Metode Penentuan Resistensi Plasmodium vivax Terhadap Klorokuin. Majalah Kedokteran Andalas No.2. Vol.32. Juli - Desember.

Perlmann, P. and Troye-Blomberg, M. (2002). Malaria Immunology: 2nd, revised, and enlarged edition. Basel: Kargel.

Richardson, M.J and L. Sauchyn. (2007). A Population Genetics Model of Malaria (Plasmodium berghei) Resistance in the Mosquito Vector Anopheles Stephensi. University of Alberta, Canada.

Rieckman K, Davis DR, Hutton DC. (1989). Plasmodium vivax resistance to chloroquine. Lancet. 18: 1183-4.

Ropivia J, Derbrè S, Rouger C, Pagniez $F$, Pape PL, Nand Richomme P. (2010). Isoquinolines from the Roots of Thalictrum flavum $\mathrm{L}$. and Their Evaluation as Antiparisitic Compounds. Molecules. 15:647684.

Rosenthal PJ. (2003). Review Antimalarial Drug Discovery: Old and New Approaches. The Journal of Experimental Biology. (2003); 206(21): 3735-44.

Sriwilaijareon, N., Petmitr, S., Mutirangura, A., Ponglikitmongkol M., Wilairat, P. (2002). Stage specificity of Plasmodium falciparum telomerase and its inhibition by berberine. Parasitology International. 51 (1); 99-103

Sullivan, D.J. and Krishna, S. (2005). Malaria: Drugs, Diseases, and Post-genomic Biology. Berlin: Springer.

Taylor, S. and V. Berridge. (2006). Medicinal Plants and Malaria: An Historical Case Study of Research at the London School of Hygiene and Tropical Medicine in the Twentieth Century. Review.The Royal Society of Tropical Medicine and Hygiene. London.

Titanji V PK, Zofou D, NGemenya MN. (2008). The Antimalarial Potential of Medicinal plants Used for the Treatment of Malaria in Cameroonian Folk Medicine. Afr J 
Tradit Complement AlternMed. 5(3): 302-32L.

World Health Organization. (2010). Guidelines for the Treatment of Malaria, Second Edition. Jenewa: World Health Organization.

Wright CW, Marshall SJ, Russel PF, et al. (2000). Article: In Vitro Antiplasmodial, Antiamoebic, and Cytotoxic Activities of Some
Monomeric Isoquinoline Alkaloids. J. Nat. Prod., 63 (12), pp 163840.

Zucker, J.R. (1996). Changing patterns of autochthonous malaria transmission in the United States: A review of recent outbreaks. Emerging Infectious Diseases. 2, 37-43. 